\title{
Twelve tips on engaging learners in checking health care decisions
}

Citation for published version (APA):

Sibbald, M., de Bruin, A. B. H., \& van Merrienboer, J. J. G. (2014). Twelve tips on engaging learners in checking health care decisions. Medical Teacher, 36(2), 111-115.

https://doi.org/10.3109/0142159X.2013.847910

Document status and date:

Published: 01/02/2014

DOI:

10.3109/0142159X.2013.847910

Document Version:

Publisher's PDF, also known as Version of record

Document license:

Taverne

Please check the document version of this publication:

- A submitted manuscript is the version of the article upon submission and before peer-review. There can be important differences between the submitted version and the official published version of record.

People interested in the research are advised to contact the author for the final version of the publication, or visit the DOI to the publisher's website.

- The final author version and the galley proof are versions of the publication after peer review.

- The final published version features the final layout of the paper including the volume, issue and page numbers.

Link to publication

\footnotetext{
General rights Owners
rights.

- You may freely distribute the URL identifying the publication in the public portal. please follow below link for the End User Agreement:

www.umlib.nl/taverne-license

Take down policy

If you believe that this document breaches copyright please contact us at:

repository@maastrichtuniversity.nl

providing details and we will investigate your claim.
}

Copyright and moral rights for the publications made accessible in the public portal are retained by the authors and/or other copyright owners and it is a condition of accessing publications that users recognise and abide by the legal requirements associated with these

- Users may download and print one copy of any publication from the public portal for the purpose of private study or research.

- You may not further distribute the material or use it for any profit-making activity or commercial gain

If the publication is distributed under the terms of Article $25 \mathrm{fa}$ of the Dutch Copyright Act, indicated by the "Taverne" license above, 


\title{
Medical Teacher
}

\section{Twelve tips on engaging learners in checking health care decisions}

\author{
Matthew Sibbald, Anique B. H. de Bruin \& Jeroen J. G. van Merrienboer
}

To cite this article: Matthew Sibbald, Anique B. H. de Bruin \& Jeroen J. G. van Merrienboer (2014) Twelve tips on engaging learners in checking health care decisions, Medical Teacher, 36:2, 111-115, DOI: 10.3109/0142159X.2013.847910

To link to this article: https://doi.org/10.3109/0142159X.2013.847910

曲 Published online: 21 Nov 2013.

Submit your article to this journal $₫$

Lll Article views: 645

Q View related articles $\asymp$

View Crossmark data \lceil

4 Citing articles: 3 View citing articles 


\title{
Twelve tips on engaging learners in checking health care decisions
}

\author{
MATTHEW SIBBALD ${ }^{1,2,3}$, ANIQUE B. H. DE BRUIN ${ }^{3}$ \& JEROEN J. G. VAN MERRIENBOER ${ }^{3}$ \\ ${ }^{1}$ University of Toronto, Canada, ${ }^{2}$ University Health Network, Canada, ${ }^{3}$ Maastricht University, The Netherlands
}

\begin{abstract}
Background: Checking diagnostic and management decisions can help reduce medical error, however, little literature explores how this is best taught.

Aims: To provide practical advice to direct teaching practices.

Methods: The authors conducted a literature review using Medline and PsychInfo using search terms: check or checklist and medical error or diagnostic error, supplemented by a manual search through cited literature.
\end{abstract}

Conclusion: Twelve tips for teaching how to check diagnostic and management decisions are presented.

\section{Introduction}

Do you check your work? Checking decisions is an important part of health care, yet physicians rarely focus on it. Worse still, physicians receive little formal training on how to check. Nurses, pharmacists and airline pilots are routinely taught how to check, but this is not a common component of medical school or residency curricula.

The nature of the health problems creates a need for checking. The problems are complex (Glouberman \& Zimmerman 2002). Decisions are not made in a vacuum, but the result of a therapeutic bond between a patient and health care provider within a healthcare environment. No two decision processes are exactly alike. Nor does disease consistently follow textbook descriptions. It is inherently unpredictable. Checking helps combat these challenges giving physicians a systematic approach to re-evaluating diagnoses and revising management plans.

However, this requires a cultural shift. Traditionally, patients and students looked to physicians, always expecting an answer, and never a mistake (Leape 1994). Teaching checking requires us to dispel these assumptions. Decisions are not the product of faultless physician authorities, but rather the humbling product of human beings trying their best with limited cognitive resources in a complex error-prone system (Henriksen \& Brady 2013). Understanding that errors result from multiple predisposing system or latent factors helps reorient trainees to be on the lookout for errors (Reason 2000). Systematic checking promotes a "culture of safety" by providing an additional safety net to catch errors before they impact patients (Shillito et al. 2010). In this article, we provide practical advice on how to highlight the importance of checking, and how to make it effective.

\section{Tip 1}

\section{Share an anecolote}

Medical errors are common (Kohn et al. 2000; Shojania et al., 2003; Graber et al. 2005; Graber 2013). Trainees often recount statistics learned in a lecture, and describe important system factors that contribute. However, trainees rarely recognize these statistics in their daily ward round, afternoon clinic, OR list or overnight call shift. Worse, trainees sometimes have the impression that medical error is an inevitable consequence of a complex healthcare system, where physicians are rarely responsible for adverse outcomes. While changing the system is undoubtedly important, so is checking your work. Trainees who blame the system are less likely to scrutinize their decisions or change their practice after making a mistake (Wu et al. 2003). Our advice - share a personal anecdote where checking failed or succeeded. Show by example how the statistics apply to everyone. Create the expectation that errors should be discussed, and that physicians have a responsibility to check their decisions. Encourage trainees to see checking as part of their job description (Nance 2008).

\section{Tip 2}

\section{Teach checking as a separate task}

Deciding and checking are different tasks, which likely benefit from different approaches. While much is known about how physicians decide, less is known about how they should check. The cognitive psychology literature describes two different sets of processes that physicians integrate - easy and quick subconscious system 1 processes that take 
advantage of patterns recognized from experience - and the deliberation of slow, effortful analytic system 2 processes (Stanovich 1999; Evans 2010). While errors made by expert physicians are frequently blamed on overuse of system 1 processes, system 1 processes are efficient and usually yield correct solutions (Gigerenzer \& Todd 1999). Most models of clinical decision-making acknowledge that physicians rely mostly on the intuition provided by system 1 processes, deferring to system 2 processes when an answer is not readily available (Croskerry 2009; Charlin et al. 2012). However, this approach does not work when checking a decision. To find and fix a mistake, slow deliberate system 2 processing is required (Sibbald \& De Bruin 2011). Even for experienced physicians, the details probably need to be verified and scrutinized in a systematic way (Moulton et al. 2007; Nance 2008; Gawande 2009; Moxley et al. 2012; Sibbald et al. 2013b). Teach trainees that making decisions and checking those decisions are different tasks with different approaches. Role model by checking a decision aloud - for example, if you are grappling with a diagnostic decision, review the evidence for and against your chosen diagnosis pointing out the relevant differential diagnosis and discriminating features. Alternately, involve trainees in the task by assigning them the job of checking the components of management plan, being sure to provide feedback on the process they used.

\section{Tip 3}

\section{Create checking moments}

Physicians have to decide when to check. Rather than waiting for a convenient time, checking needs to be planned, as part of the regular day's work. Parts of the daily routine lend themselves readily to checking - after drawing blood, after admitting a patient, before conducting a procedure, or after writing a prescription. For instance, many have advocated for a diagnostic "time out" to revisit diagnostic decisions, which feels natural at the end of a consult or admission (Trowbridge 2008; Graber et al. 2012). A similar opportunity is present before starting a procedure, where "time outs" reduce perioperative complications and may even impact peri-procedural patient mortality (Haynes et al. 2009).

\section{Tip 4}

\section{Make checking a habit}

Certain situations are particularly error prone. Seasoned physicians have warning bells go off when they prescribe weekly methotrexate, a toxic immunosuppressant, occasionally taken daily in error with disastrous results. These common patterns can be stored in physicians' minds as error prototypes or "error scripts", similar to disease prototypes or "illness scripts" (Schmidt \& Rikers 2007; Mylopoulos et al. 2012). These error scripts can cue physicians to double-check in error prone contexts. Help trainees develop their own error scripts by pointing these situations out - like the pre-procedure check to ensure the right patient and the right side of the body is being prepared. However, not all errors can be anticipated, or occur in error-prone contexts. As a result, checking needs to be a regular habit. Encourage trainees not to skip regular checking because they are in a rush or because someone else insists.

\section{Tip 5}

\section{Avoid skipping checks in crises}

Unfortunately, sticking to a routine, which incorporates regular checking, is not easy in an acute crisis. Well-intentioned physicians will often bypass steps in an attempt to save time when it matters most (Beatty \& Beatty 2004). For instance, using a checklist to verify sterility before central line insertion is easy to skip when a patient is critically ill and needs urgent resuscitation. However, these violations - the term used to describe a conscious choice to skip a safety check - can put patients at risk for additional complications when already very ill. Encourage trainees to make use of checking routines during acute crises. Even in the most dire of situations when a patient has arrested - using pre-printed checklists improves timely administration of life saving treatment (Arriaga et al. 2013).

\section{Tip 6}

\section{Teach frameworks}

Trainees may find it challenging to identify what do to when checking their decisions. Trainees may avoid checking their decisions because they simply do not know how to go about it, or may be so preoccupied in their attempts to be systematic that they have trouble spotting mistakes. Using terms provided by cognitive load theory, the mental effort required to check is a combination of the extraneous load of deciding how to check, and the intrinsic load of actually checking (van Merrienboer \& Sweller 2010). Unfortunately, extraneous and intrinsic load must compete for our limited attention. By adopting a systematic framework, the extraneous load of checking can be reduced, allowing trainees to focus on finding mistakes. Often, these frameworks are organized into checklists, which have helped physicians reduce error in a variety of contexts (Wolff et al. 2004; Haynes et al. 2009; Winters et al. 2009; Ely et al. 2011; Arriaga et al. 2013; Sibbald et al. 2013).

Many checklists focus on the key variables involved in a diagnostic or management decision (Hales et al. 2008). For instance, in ECG interpretation, successful checklists involve reviewing the rate, rhythm, axis, waves and intervals (Sibbald et al. 2013). Alternatively, for chest radiographs, checklists are often derived from all the anatomic structures, arranged in a easy to remember order beginning with the most external structures (soft tissues, bones, pleura, lung, mediastinum, hila, cardiac structures, abdomen) (Berbaum et al. 2006). Many diagnostic skills in medicine are taught using similar frameworks that can be repurposed as checking tools. This type of tool which focuses attention on key variables have been studied in many other fields outside of medicine, 
frequently showing benefit above and beyond usual expert decision-making (Grove et al. 2000).

\section{Tip 7}

\section{Use checklists before procedures}

A robust literature base supports the use of pre-procedural checklists (Gawande 2009; Haynes et al., 2009; Goeschel et al. 2010). Procedures are particularly prone to error because they frequently involve coordination between many health care professionals in a timely manner. Frequently, physicians who are doing the procedure are focused on technical aspects, naturally predisposing to slips and lapses. Preprocedural checklists address common variables that are easily overlooked (e.g. is the right patient and the right side of the body prepared?). Checklists also help coordinate the team. For instance, checklists can ensure that antibiotic prophylaxis to prevent surgical site wound infections is administered by the anesthesiologist within $30 \mathrm{~min}$ of the surgeon cutting the skin (Haynes et al. 2009).

\section{Tip 8}

\section{Ask trainees to verify and recollect key data}

As most first year residents quickly realize, medical information is always in flux. Did the chest pain get worse with exertion? The patient is unsure - the resident interprets this as "non-exertional chest pain". But when questioned a second time by the staff physician - "it did seem to get worse with walking". The history changes when patients are given time to reflect on their symptoms.

The available information is always changing: medical conditions evolve, patients suddenly remember relevant details, and imaging interpretations are revised. Physicians rely on this primary data to make their decisions, and must verify this primary data when they check their decisions.

Even if the data are not changing, there may be value in revisiting the primary dataset. Because physicians usually develop hypotheses early in the patient encounter (or when reviewing imaging), they do not simply passively collect a large set of data, but carefully direct data collection to rule out alternatives or 'rule in' the most likely diagnosis (Elstein et al. 1978). While efficient, this process allows physicians to be influenced by a variety of sources of bias. For instance, it is natural to pay particular attention to information that supports the working hypothesis (confirmation bias), or avoid seeking additional information (premature diagnostic closure) (Redelmeier 2005). By recollecting information in a systematic framework, physicians can decrease the chance they will be influenced by these biases (Sibbald, et al. 2013). Reinforce to trainees that when they check, they need to verify the primary data. Have them pull up radiology reports or blood culture results on rounds. Have them double check with a patient about allergies prior to administering antibiotics.

\section{Tip 9}

\section{Teach verbalization as a checking tool}

Many seasoned physicians recognize the value of "talking through a case" with a colleague, or find themselves pausing while dictating a note realizing they have overlooked an important piece of information. Viewing something and talking about it result in fundamentally different ways of processing the information, which both facilitate automatic recognition or priming (Schacter 1992). Many successful checklists have been designed to force physicians to verbalize their checking, often to ensure that they are actually doing it or to share the information with other health professionals, such as the pre-operative checklist (Haynes et al. 2009). However, verbalization has been found valuable in other contexts. Asking radiologists to verbalize their interpretation improves ability to detect a second abnormality, combating a problem called "satisfaction of search" where physicians stop looking after detecting an obvious abnormality (Berbaum et al. 2006). Trainees can be encouraged to verbalize their checking behaviors in a couple of ways. Rather than asking a trainee to justify a decision aloud, ask them to check their decisions. Require trainees to dictate their consultations - not only will it help develop their communication skills, but encourage them to verbalize the primary dataset.

\section{Tip 10}

\section{Integrate other health professionals}

A common defense against violations is to task another healthcare professional with ensuring that checking is completed (Nance 2008; Gawande 2009). For instance, operating room charge nurses are commonly asked to ensure that preoperative checklists are complete before allowing surgery to proceed. Similarly, some intensive care units have nurses fill out central line insertion checklists to ensure sterile technique is followed. While this division of responsibility is sometimes seen as threatening physician autonomy, it has also resulted in significant improvements in patient care. Encourage trainees to see the benefit in engaging other healthcare professionals to make patient care as safe as possible.

\section{Tip 11}

\section{Engage patients in the checking process}

Many physicians have faced an inquisitive and sometimes doubtful patient who asks, "are you sure?" While physicians sometimes interpret this type of questioning as a threat to their credibility, physicians can also use it opportunistically to double check pertinent information and revisit a diagnosis or management plan. Some physicians dictate consultation letters in the presence of patients, which allows patients the opportunity to correct details. Similarly, pre-procedural checklists engage patients in ensuring all the information is correct. Encourage trainees to involve patients when they check 
diagnostic or management decisions, and to take advantage of checking opportunities provided by doubtful patients.

\section{Tip 12}

\section{Role model checking}

Trainees emulate what they see being done. Seeing a wellrespected senior physician pause to verify key information or reconsider a diagnosis sends a powerful message to trainees: we all need to check. Emphasize that even experts benefit from checking (Sibbald et al. 2013). Checking is not simply a process for novices to avoid mistakes, but helps even experienced health care professionals reduce active failures in a complex healthcare system prone to medical error. Role model good checking behaviors, and point out when errors are detected to help foster the attitude that checking is important.

\section{Conclusion}

Developing robust error checking routines is an important skill in a competent physician's arsenal. Teachers can help trainees develop this skill by engaging them in checking and providing feedback. Teachers should highlight characteristics of good checking behaviors: frequent, habitual, analytic, frameworkdriven and team-based.

Declaration of interest: The authors report no conflicts of interest.

\section{Notes on Contributors}

MATTHEW SIBBALD, MD MHPE, is a research scientist at the Center for Excellence in Education and Practice at the University of Toronto.

ANIQUE DE BRUIN, PhD, is an assistant professor at Maastricht University. JEROEN J. G. VAN MERRIENBOER, PhD, is a Professor of Learning and Instruction at Maastricht University.

\section{References}

Arriaga AF, Bader AM, Wong JM, Lipsitz SR, Berry WR, Ziewacz JE, Hepner DL, Boorman DJ, Pozner CN, Smink DS, Gawande AA. 2013. Simulation-based trial of surgical-crisis checklists. New Engl J Med 368(3):246-253.

Beatty P, Beatty S. 2004. Anaesthetists' intentions to violate safety guidelines. Anaesthesia 59(6):528-540.

Berbaum K, Franken Jr. EA, Caldwell RT, Schartz KM. 2006. Can a checklist reduce SOS errors in chest radiography? Acad Radiol 13(3):296-304.

Charlin B, Lubarsky S, Millette B, Crevier F, Audetat MC, Charbonneau A, et al. 2012. Clinical reasoning processes: Unravelling complexity through graphical representation. Med Educ 46(5):454-463.

Croskerry P. 2009. A universal model of diagnostic reasoning. Acad Med 84(8):1022.

Elstein A, Schulman L, Sprafka S. 1978. Medical problem-solving: An analysis of clinical reasoning. Cambridge: Harvard University Press.

Ely J, Graber M, Croskerry P. 2011. Checklists to reduce diagnostic errors. Acad Med 86:307-313.
Evans J. 2010. Thinking twice: Two minds in one brain. Oxford: Oxford University Press.

Gawande A. 2009. The checklist manifesto: How to get things right. New York: Metropolitan Books.

Gigerenzer G, Todd PM. 1999. Fast and frugal heuristics: The adaptive toolbox Simple heuristics that make us smart. New York: Oxford University Press. pp 3-34.

Glouberman S, Zimmerman B. 2002. Complicated and complex systems: What would successful reform of medicare look like? Saskatoon: Commission on the Future of Health Care in Canada.

Goeschel CA, Holzmueller CG, Cosgrove SE, Ristaino P, Pronovost PJ. 2010. Infection preventionist checklist to improve culture and reduce central line-associated bloodstream infections. Jt Comm J Qual Patient Saf 36(12):571-575.

Graber M, Franklin N, Gordon R. 2005. Diagnostic error in internal medicine. Arch Intern Med 165(13):1493-1499.

Graber M, Kissam S, Payne V, Meyer A, Sorensen A, Lenfestey N, et al. 2012. Cognitive interventions to reduce diagnostic error: A narrative review. BMJ Health Qual Safety 21(7):535-557.

Graber ML. 2013. The incidence of diagnostic error in medicine. BMJ Qual Safe 22(Suppl 2):ii21-ii27. doi: 10.1136/bmjqs-2012-001615.

Grove W, Zald D, Lebow B, Snitz B, Nelson C. 2000. Clinical versus mechanical prediction: A meta-analysis. Psychol Assess 12(1):19-30.

Hales B, Terblanche M, Fowler R, Sibbald W. 2008. Development of medical checklists for improved quality of patient care. Int J Qual Health Care 20(1):22-30.

Haynes AB, Weiser TG, Berry WR, Lipsitz SR, Breizat AH, Dellinger EP, et al. 2009. A surgical safety checklist to reduce morbidity and mortality in a global population. N Engl J Med 360(5):491-499.

Henriksen K, Brady J. 2013. The pursuit of better diagnostic performance: A human factors perspective. BMJ Qual Safe 22(Suppl 2):ii1-ii5. doi:10.1136/bmjqs-2013-001827.

Kohn LT, Corrigan J, Donaldson MS. 2000. To err is human: Building a safer health system, Vol. 6. Washington: Joseph Henry Press.

Leape LL. 1994. Error in medicine. JAMA US Edition, 272(23):1851-1856.

Moulton C, Regehr G, Mylopoulos M, MacRae H. 2007. Slowing down when you should: A new model of expert judgment. Acad Med 82(10):S109-S116.

Moxley JH, Anders Ericsson K, Charness N, Krampe RT. 2012. The role of intuition and deliberative thinking in experts' superior tactical decisionmaking. Cognition 124(1):72-78.

Mylopoulos M, Lohfeld L, Norman G, Dhaliwal G, Eva KW. 2012. Renowned physicians' perceptions of expert diagnostic practice. Acad Med 87(10):1413-1417.

Nance JJ. 2008. Why hospitals should fly: The ultimate flight plan to patient safety and quality care. Bozeman, MT: Second River Healthcare Press.

Reason J. 2000. Human error: Models and management. $\mathrm{Br}$ Med J 320(7237):768-770.

Redelmeier DA. 2005. The cognitive psychology of missed diagnoses. Ann Intern Med 142(2):115-120.

Schacter DL. 1992. Priming and multiple memory systems: Perceptual mechanisms of implicit memory. J Cogn Neurosci 4(3):244-256.

Schmidt H, Rikers R. 2007. How expertise develops in medicine: Knowledge encapsulation and illness script formation. Med Educ 41:1133-1139.

Shillito J, Arfanis K, Smith A. 2010. Checking in healthcare safety: Theoretical basis and practical application. Int $\mathrm{J}$ Health Care Qual Assur 23(8):699-707.

Shojania KG, Burton EC, McDonald KM, Goldman L. 2003. Changes in rates of autopsy-detected diagnostic errors over time: A systematic review. J Am Med Assoc 289(21):2849-2856.

Sibbald M, De Bruin AB. 2011. Feasibility of self-reflection as a tool to balance clinical reasoning strategies. Adv Health Sci Educ, DOI 10.1007/s10459-011-9320-5.

Sibbald M, de Bruin AB, Cavalcanti RB, van Merrienboer JG. 2013a. Reexamination with a cognitive checklist improves cardiac diagnosis. BMJ Qual Saf 0:1-6. 
Sibbald M, de Bruin AB, van Merrienboer JJG. 2013b. Do checklists improve experts' diagnostic decisions? Med Educ 47(3):301-308.

Stanovich K. 1999. What is rational? Studies of individual differences in reasoning. Mathway: Lawrence Elrbaum Associates.

Trowbridge RL. 2008. Twelve tips for teaching avoidance of diagnostic errors. Med Teacher 30(5):496-500.

van Merrienboer JJ, Sweller J. 2010. Cognitive load theory in health professional education: Design principles and strategies. Med Educ 44(1):85-93.
Winters BD, Gurses AP, Lehmann H, Sexton JB, Rampersad CJ, Pronovost PJ. 2009. Clinical review: Checklists-translating evidence into practice. Crit Care 13(6):210-219.

Wolff AM, Taylor SA, McCabe JF. 2004. Using checklists and reminders in clinical pathways to improve hospital inpatient care. Med J Austra 181:428-431.

Wu A, Folkman S, McPhee S, Lo B. 2003. Do house officers learn from their mistakes? Qual Saf Health Care 12(3):221-226. 